\title{
Cost free medical team training
}

\author{
Dan Brun Petersen ${ }^{1 *}$, Frank Østergaard Hansen ${ }^{1}$, Peter Bisgaard Stæhr ${ }^{1}$, Anne Skovbakke Jensen ${ }^{2}$ \\ From Danish Society for Emergency Medicine: Research Symposium 2010 \\ Roskilde, Denmark. 20-21 May 2010
}

\section{Background}

Medical simulation and team training is widely used and the effect on learning is generally accepted. However, full scale simulation is expensive and time consuming. Mornings in the Emergency Department (ED) are often quiet leaving time for other activities.

The trauma teams are well organized, and they participate in team training regularly. In contrast, even though medical and surgical patients are often at least as complex as trauma patients, they are managed only by a few nurses and a junior physician, and the team work is rarely trained.

We wanted to test the feasibility of a simple and costfree setup, aimed at increasing the teamwork abilities of our staff.

\section{Methods}

The training was organized by two junior physicians, both ALS provider trained, and a nurse specialist, ATCN educated. It took place in a regular ED room with a simple CPR manikin torso.

On three separate days, two teams consisting of 2 nurses and 2 junior physicians from the ED were selected. The two teams went through a scenario from 8.30 to $9.00 \mathrm{am}$, and from 9.00 to $9.30 \mathrm{am}$, respectively.

The organizing physician explained the scenario and gave information about the manikin's reply and status. Vital signs were written on a piece of paper, changing as the scenario progressed. The teams were instructed to act as they would in a real clinical situation, e.g. talk to the patient and the team and to carry out relevant procedures. After finishing the scenario five minutes were used for debriefing of the team.
* Correspondence: danbrun@gmail.com

${ }^{1}$ Acute Admission Unit, Kolding Sygehus, Kolding, Denmark

Full list of author information is available at the end of the article

\section{Results}

12 nurses and 12 junior physicians had basic team training in a simulated clinical situation, while a similar number of staff observed. All active participants found the training highly valuable. The training also revealed that some essential utensils and medications for resuscitation were too far away from the regular ED room. Hence, part of the ED was reorganized on the basis of these observations.

\section{Conclusion}

Basic medical team training can be carried out without advanced equipment and with no cost if fitted into the daily programme. It is also a valuable way to test the equipment and physical set-up of the ED.

\section{Author details \\ ${ }^{1}$ Acute Admission Unit, Kolding Sygehus, Kolding, Denmark. ${ }^{2}$ Emergency Room, Kolding Sygehus, Kolding, Denmark.}

Published: 17 September 2010

doi:10.1186/1757-7241-18-S1-P7

Cite this article as: Petersen et al:: Cost free medical team training.

Scandinavian Journal of Trauma, Resuscitation and Emergency Medicine 2010 18(Suppl 1):P7

Submit your next manuscript to BioMed Central and take full advantage of:

- Convenient online submission

- Thorough peer review

- No space constraints or color figure charges

- Immediate publication on acceptance

- Inclusion in PubMed, CAS, Scopus and Google Scholar

- Research which is freely available for redistribution

Submit your manuscript at www.biomedcentral.com/submit
Biomed Central 